УДК 821.161. - 343 - 312.9

DOI: 10.31475/fil.dys.2019.09.15

ОЛЕНА САЗОНОВА, кандидат фбілологічних наук, дочент (л. Чернігів); АНАСТАСІЯ ПРИМОЧЕНКО, студентка (л. Чернігів)

\title{
Особливості міфопоетики слов'янського фентезі в авторській інтерпретації Дари Корній і Тали Владмирової
}

Розглянуто особливості прояву авторської міфбологї Дари Корній i Тали Владмирової у творі "Крила кольору хлар" з урахуваннял слов'янської національної традииї й зарубіжного досвіду літературного жанру ббентезі. Спостережено, як дотрилано у фбентезійному тексті канонів та структурних елелентів давньоукраӥнської міфбологї̈ й ббольклору, як вплетені у художній простір ббентезі міфбологічні уявлення, архетипні образи, силволи, сюжети. Досліджено основну проблематику твору. Вивчено образи головних героїв та здійснено пошук їх праобразів в українській міфбологї, виділено фбнкиії дійових осіб.

Ключові слова: фбентезі, ліфбопоетика, силволи, власне «я", персонаж.

Постановка проблеми в загальнолу вигляді... Демократичні зміни в суспільстві, безперечно, відчуваються в художній літературі, оскільки вона має публічність та повинна за своїм функціональним призначенням реагувати на замовлення сощіуму. Позбавлення красного письменства соціалістичних ідеологем спонукало авторів до активних пошуків виявлення власного «я» за межами об'єктивної реальності, що призвело до чергового Ренесансу в літературі та зумовило звернення до популярного на теренах Заходу жанру фентезі. За доречним спостереженням Галини Бокшань, «українське письменство, позбувшись диктату канонів так званого «соцреалізму», почало надолужувати свое відставання від світового літературного процесу наприкінці XX ст. Неоміфологізм був органічно притаманний нашому мистецтву слова в епоху модернізму, став одним із пріоритетних художніх напрямів для вітчизняних неомодерністів i постмодерністів» [2, с. 1]. У контексті міфрологічних схем та принципів зображення прозаїки прагнуть осмислити антропологічні та глобальні 
проблеми сучасності - духовне звиродніння, занепад культури та розвиток цивілізації, що призвів до екологічних катастрофр.

Аналіз досліджень $і$ публікаuій... У науковий обіг термін «фентезі» вперше увів американський критик Хьюго Гернсбек, використавши його у статтях 1926-1928 pp., чітко відмежовувавши від наукової франтастики, названої ним science fiction [16]. Оскільки вітчизняна література тривалий час розвивалася в заідеологізованому просторі, тож розвиток жанру фентезі припав на значно пізнійший час - 90-і рр. ХХ ст., лише у 2000-х почали з'являтися спорадичні розвідки літературної критики щодо його осмислення. У 2011 р. на засіданні кафедри історії та теорї світової літератури КНЛУ «було висловлено припущення про виокремлення фентезі новітньої доби у самостійне явище, що груктується на спостереженні за поетикальними особливостями, рисами світогляду сучасної людини, рднак зауважено, що в них простежуються певні відлуння світогляду й поетики доби Барокко» [5, с. 28]. За ініціативи Євгенії Канчури, кандидата філологічних наук, співголови Центру 3 дослідження літератури фентезі при Інституті літератури ім. Тараса Шевченка НАН України та за редагування Тетяни Рязанцевої у 2018 р укладено Збірник матеріалів наукового семінару Центру 3 Дослідження Літератури Фентезі при Інституті літератури ім. Т. Г. Шевченка НАН України за $2016-2017$ рp. [5].

Виокремили загалом елементи фантастики в художньому творі I. Буркут, О. Ковтун, Т. Чернишова. Надалі франтастику розглядали як окремий жанр епосу Тетяна Бовсунівська, Є. Брандіс, К. Мзареулов. Поетика франтастичного (фентезійного) часопростору приваблювала А. Нямцу. Науковці заявили про фентезі як особливий різновид фантастики, прослідкували за генеалогією френтезі О.Леоненко, Н. Логвіненко, М. Назаренко, Т. Савицька. С. Олійник, Н. Савицька, О. Стужук зупинилися на компаративному аналізі франтастичної літератури. О. Ковтун пропонує класифікувати літературні твори за типом літературної умовності, на такі, що містять «стовідсоткову вигадку», а також на ті, що оповідають про те, чого «не буває» або ті, «взагалі такого не може бути» [9]. Дослідники прагнули подати термінологічну базу для цього явища, оперуючи такими поняттями, як: «рантастичний жанр» (В. Державін), «франтастична література» (Ц. Тодоров, А. Осипов), «наукова франтастика» (Ю. Кагарлицький, Т. Чернишова, А. Нямцу), «підгрупа франтастики», «ігрова франтастика» (О. Стужук), «казка для дорослих» (Н. Дев'ятко, О. Романенко), «фентезі» (Б. Давенпорт, М. Назаренко, В. Сшкілєв), «наукове френтезі» (технофрентезі) (Р. Желязни), «соціально-утопічна франтастика» 
(Н. Чорна, Г. Гуревич, Т. Чернишова) тощо. Дослідників цікавлять різні аспекти жанру франтастики та фентезі. Так, Н. Криницька розробила методологію онтологічної поетики франтастичної літератури [13]. О. Цалапова, використовуючи порівняльний аналіз до творів раннього українського модернізму (Дніпрова Чайка, Леся Українка, Олександр Олесь, Михайло Коцюбинський), виявила у них міфропоетику казкового світу [17]. А. Гурдуз визначено типологію, принщипи побудови «міфопоетичних систем ряду «жіночих» містичних любовних романів - «Зла» Людмили Баграт 2002 р., «Дзеркала єдинорога» Людмили Таран 2008 р. і «Гонихмарника» Дари Корній (Мирослави Замойської) 2010 р.», а також «риси спорідненості i своєрідності їх міфопоетичних парадигм» [6, с. 61-62]. Дослідник виявив жанрові ознаки фентезі у романі «Гонихмарник» Дари Корній, висвітлив аналогії, співвіднесеності із іншими сучасними творами цього жанрового спрямування, спробував віднайти праобразів в українській міфології до образів головних героїв [7]. Крім того, розвідки А. Гурдуза присвячені висвітленню природи «міфопоетики, міфротворчості, зокрема, авторського міфу, визначенню характеру міфопоетичної парадигми певної художньої фрормації в системі літературного процесу» [6, с. 61]. С. Олійник розглянуто міфологеми вогню, води, повітря і землі у творах «Мідний король» Марини і Сергія Дяченків, «Балада для кривої Варги» та «Херем» Марини Соколян, дилогії «Циклоп» Генрі Лайон Олді, зауважено, що вони «слугують своєрідними кріпленнями, на які нанизуються міфологічні уявлення, вплетені у художній простір фентезі на всіх рівнях побутування тексту творів» $[14$, с. 116]. Вивчення сучасного неоміфологізму в українській літературі потребуе всебічного вивчення, чому сприятиме дослідження конкретного матеріалу.

Форлулювання иілей статті... Мета дослідження - окреслити специфіку міфопоетики слов'янського френтезі в українському фентезійному творі Дари Корній і Тали Владмирової «Крила кольору хмар».

Виклад основного матеріалу... Прообразами жанру френтезі в українській літературі варто вважати водевіль «Москаль-чарівник» (1819 р.) I. Котляревського, цикл «Вечори на хуторі біля Диканьки» (1829-1832 рр.), оповідання «Портрет» (1834 р.), повість «Вій», уміщену в книзі «Миргород» 1835 р. М. Гоголя, повість «Конотопська відьма» (1837 р.), опублікована в другій книзі «Малоросійських оповідань» Г. Квітки-Основ'яненка, балади «Причинна» (1837р.), «Тополя» (1838 р.), поема «Відьма» (первісний варіант назви - «Осика», 1847 р.), драму-фреєію «Лісова пісня» Лесі Українки (1911 р.), а також повість 
«Тіні забутих предків» М. Коцюбинського (1911р.). У цих творах спостерігаемо використання слов'янської міфрології, чітко можемо простежити явище міфопоетики, що для жанру френтезі $є$ показовим елементом. Елементи фентезі містяться ще в козацьких літописах (Самовидця, Величка, Граб'янки)», зокрема у лихих спробах мертвих підпалити церкву, у їх несамовитому виході 3 криниць, чим вони навіяли жах на оточення, тож ці тексти мають ознаки раннього хорору. Зараховують до героїчного фентезі з «досить складною і вишуканою жанрово-виконавською конструкціею «Енеїду» Івана Котляревського» [4]. Якщо світове фентезі на сьогодні досить ретельно проаналізовано, то феномен українського фентезі заслуговує на всебічне дослідження, адже українська література вкотре перебуває в стані пошуків самоідентичності. На думку Дари Корній, «містика присутня у житті кожного з нас, але дехто воліе її не бачити. Певно боїмося виходити із зони комфорту. Діти більш відкриті і мобільні у цому питанні. Вони можуть бачити такі речі, які дорослі пропускають. Містика - це тонкий світ, який існуе біля нас» [15].

Твори Дари Корній ще мало досліджені, хоча їі часто порівнюють із авторкою «Сутінок» Стефані Маєр. Деякі аспекти творчого доробку письменниці розглянуто в розвідках А. Гурдуз «Метагероїня романів Дари Корній» та «Крила кольору хмар» Дари Корній і Тали Владмирової: проблеми традицій й новаторства в романі». Однак залишається ще багато не досліджених аспектів художньої мови роману. Українські народні казки, притчі, легенди, перекази, народні звичаї, ритуали, замовляння, заклинання, пісні, ігри становлять великий інтерес для дослідників. Адже там розкривається історія справжнього життя нашого народу. За словами Дари Корній, «глибоке

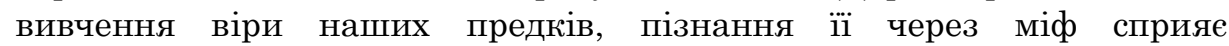
пробудженню і в молоді історичної пам'яті та формуванню національної гідності й самосвідомості» [1].

Дара Корній (Мирослава Іванівна Замойська) - відома українська письменниця, на рахунку якої понад чотирнадцять романів, у 2010 році стала лауреатом третьої премії «Коронації слова» за роман «Гонихмарник». Разом з Талою Владмировою (Тамілою Тарасенко) написали два спільних твори: «Зозулята зими» та «Крила кольору хмар». У фейтезійному романі Дари Корній і Тали Владмирової «Крила кольору хмар фундаментом міфопоетики стають численні образаисимволи. Найголовнішим символом роману е крила, і варто зазначити, що для Дари Корній цей символ є мандрівним, адже письменниця активно використовуе його і в інших своїх творах. Велика увага в романі приділена саме забарвленню янгольських крил: білі, темні та 
cipi: «Загадкові cipi...Ті, які не стали ні на бік світла, ані на бік темряви...Сірі янголи. Вони зараз між людьми не з доброї волі. Усе вирішили за них, і їх нема куди повертатися. На небо не візьмуть, а в пекто - завжди встигнеться так низько впасти...» [12, с. 146]. Однак, неодноразово наголошуеться, що колір крил не вирішує душевну приналежність янгола до тіеї чи іншої касти.

О. Козій у праці «Янголи XX століття: концепт крил у літературі (на матеріалі творів Г. Уеллса "Дивовижні відвідини», Г. Маркеса «Сто років самотності та оповідання «Стариган 3 крилами», оповідання А. Дімарова «Крила» та вірша І. Драча «Крила»» дослідила концепцію символіки крил у літературі, наголосила: «... на прикладі образу крил ми простежили як фрілософрські течії та літературний процес XX століття вносять зміни в сприйнятті концептів 3 архетипним підтекстом. Зниження уваги до людини як носія внутрішнього багатства в індустріальному світі призводять до зникнення віри в надприродне, знецінення поняття вищого призначення та духовного потенціалу» [10, c. 218]. Прикладом цієї тези може слугувати герой Мечислав (батько Аделаїди), який е сірим янголом, але став на бік зла, а в свою чергу, головна героїня, маючи сіре забарвлення пір'я, обрала бік добра. Тож, символ крил у романі «Крила кольору хмар» можемо тлумачити не тільки, як фундамент, на якому у творі розвивається міфопоетика за біблійними сюжетами, але і як певні кайдани для головних героїв: логічно, що янголи не мають зраджувати своїй касті, але герої бажають робити вибір самотужки, не дивлячись на забарвлення свого пір'я.

Ще одними тридищійними символами у творах Дари Корній $є$ Світло та Темрява. У «Гонихмарнику» знаходимо: «...чорне - це лишень відсутність потоку світла...» [11, с. 14], а вже у романі «Крила кольору хмар» головна героїня розмірковувала: «...що таке темрява? Невже лише відсутність світла?...А як щодо світлих чи сірих янголів? Це відсутність чи присутність когось або чогось?» [12, с. 20], зрештою, у романі по-фрілософськи потлумачено сутність Добра та Зла: «Зло - це відсутність Бога. Воно схоже на темряву і холод. Нема тепла і світла - i ми кажемо «холодно» та «темно». Відсутність Бога та божественної любові всередині людини - це і є зло. Бог не породжує зла. Він є любов. Зло живе там, де немае Бога» [12, с. 158]. Тож можемо логічно пояснити, чому Мечислав обрав бік темряви: у нього не було любові ні до рідної неньки, яку він без жодного сумніву прийняв у жертву, ані до власних доньок, на відміну від нього, головна героїня по-справжньому любила і свою бабусю, і сестру, про яку згодом дізналась і якою почала опікуватися, і Віктора. Дівчина переповнена бажанням любити. 
Відтак символи Світло та Темрява, Добро та Зло набувають додаткового значення - наявність або відсутність любові в душі героїв, їхне бажання та вміння любити інших. «Колись в українській міфрології не було чіткого поділу між добром і злом, - зазначає мольфарка слова. - Світ сприймався багатогранно. У давнину, коли люди йшли на війну, то зверталися до темного бога. А коли треба було задобрити вищі сили на щедрий врожай, зверталися до добрих богів. Тоді світ був урівноважений. Зараз з'явився поділ між злом та добром. У нашому світі ця межа стираеться. Якщо дуже довго людям утовкмачувати, що канібалізм - це добре, то з часом вони у це віритимуть і зло стане добром. Тому не треба піддаватися на спокуси. Бо вибір є завжди» [3].

Також велику увагу в романі «Крила кольору хмар» відведено образам-символам душ, які може бачити головна героїня, завдяки чому читач отримуе інтуїтивну характеристику персонажів, адже душа - це внутрішня сутність людини, за релігійними й міфологічними віруваннями, $є$ безсмертною частиною людини, що становить їі сутність і відрізняе людину від тварин, наприклад: «Квіти. Он одна велика найтепліших кольорів дуже схожа на орхідею фраленопсіс. Правда, я не люблю орхідей, бо знаю, що попри свою красу, вони - звичайнісінькі паразити, ладні висмоктати всі соки з тропічних дерев...Троянда. Ну, тут і пояснень не треба. Справжнісінька тобі королева. Полум'яна красуня...» [12, с. 97-98] або ж «Змійка...Як на мене, значно більше варто боятися двоногих. Змії хоч сичать, попереджаючи перед тим, як вкусити. I ніколи не нападають просто так. Вони бороняться. А в тому, як стрімко і водночас плавно перелискуе жива смужка, є відголосок давньої магії» [12, с. 98].

У романі Дари Корній і Тали Владмирової «Крила кольору хмар» символ душі одночасно пов'язаний як 3 біблійними міфами, так і 3 язичницькими: 3 одного боку, це святе духовне начало, а 3 іншого, кожна душа має свою форму, свій запах, колір, мають подобу або рослин, або тварин. Варто зазначити, що головна героїня є ще й дзеркалом: «Бо дзеркало - це не лише моя янголина зброя, це й велика відповідальність і тягар... Я відчуваю це, торкнувшись його душі своїм дзеркалом...Дзеркалом, яке вміє бачити людські душі. Душа - це згусток енергії. Кольоровий згусток. Кожна душа має власний колір. Душа - це світло, яке має колір. I світло завжди можна відбити...» [12, с. 139-140]. Також завдяки такому вмінню Аделаїда може захищатися, адже той, хто спрямуе на неї свою злу силу, отримуе їі назад, адже дзеркало відбиває енергію. Важливим є те, що дзеркало є як біблійним, так і язичницьким символом. У християнстві дзеркало є символом немовляти Iсуса - «Дзеркало Бога», а також Божу Матір часто 
зображують із дзеркалом, через що називають ¥ї «Дзеркалом Праведності». Водночас у різних культурах дзеркало є невідемною частиною язичницьких вірувань: у грецьких міфрах лише дзеркало було здатне вбити Медузу Горгону (відбиває силу, як це робить головна героїня роману «Крила кольору хмар»), за індійськими віруваннями, дзеркало відображае істину сутність (за цим принщипом Аделаїда бачить душі, відчуває їхній запах). Тож тут також спостерігаємо «нашарування» язичнищьких та християнських міфів, завдяки чому з'являеться якісно новий, авторський міфр. Жанр френтезі дає нове дихання старим легендам та міфрам, осучаснюе їх. На запитання про улюблене божество в одному 3 інтерв'ю Дара Корній «не назвала конкретних імен, а прощитувала слова із Велесової книги: «Бог единий, але він - багатоликий». Хоча додала, що їй дуже подобається жіночий лик творця» [8]. Саме для слов'янського френтезі $\epsilon$ показовими елементами чіткої боротьби добра та зла, що завершуеться перемогою добра, адже зарубіжні автори надають перевагу трагічності, відкритому кінцю, подвійному тлумаченню кінцівок або ж узагалі загибелі головних героїв, яскравими прикладами $\epsilon$ трилогія Саллі Грін «Напівлихий», дилогія Лі Бардуго «Шістка воронів» тощо.

Висновки... Отже, автори френтезі «не списують» вже давно вигадані історії, а лише запозичують їхні елементи, перероблюють на свій розсуд, завдяки чому виникає зовсім нова історія. В основі сюжету зазвичай є протистояння двох начал: Добра та Зла, а також важливе місце відводиться змалюванню пригод. У слов'янському фентезі також є певний типаж головного героя: людина, життя якої чарівним образом перетинаеться з магічним, іншим світом, отримуе суперздібності, де вона має робити надважкий вибір (боротися зі злом, виконати своє призначення тощо). Варто зазначити, що головний герой фентезійного твору $е$ аналогом головного героя казки: він бореться зі злом (з антигероєм), а йому допомагають істоти з міфів та легенд (янголи, ельфи, гноми, чарівники тощо).

Героями міського фентезі Дари Корній i Тали Владмирової $є$ міфічні персонажі - відьми, а також люди, наділені надприродними силами. Символи у фентезійному романі Дари Корній і Тали Владмирової «Крила кольору хмар» е фрудаментами певних міфрів, на основі яких автори створили унікальну міфопоетику, а головна героїня Аделаїда є тим центром, який утримує навколо себе всі символи твору й одночасно своїми роздумами тлумачить їх. $\mathrm{y}$ романі продовжено тенденцію «жіночої» прози про сильних жінок, де 3 появою головної героїні пов'язуеться магічна таємниця, через що дівчина стає джерелом самого поняття «френтезі» у романі. 


\section{Список використаних джерел і літератури:}

1. Бачинська Катерина. Дара Корній: Вітчизняне фентезі видавці не дуже шанують [Електронний ресурс] / Катерина Бачинська // Україна молода. - 18 вересня. - 2015 . - № 122 - $\quad$ - Режим доступу: https://www.umoloda.kiev.ua/number/2709/164/94873/

2. Бокшань Г. I. Неоміфологізм у художній прозі Галини Пагутяк:автореф. дис. ... канд. фрілол. наук: 10.01.01 «Українська література»/ Галина Іванівна Бокшань. - Київський університет імені Бориса Грінченка. - Київ, 2017. - 22 c.

3. Бондар Лілія. Мольфарка слова Дара Корній: «Запоющую очі й бачу інші світи» [Електронний ресурс] / Лілія Бондар // Волинські новини. - 2 квітня 2016. - Режим доступу: https://www.umoloda.kiev.ua/number/2709/164/94873/

4. Валентинов А. Замітки про українську фантастику. [Електронний ресурс] / Андрій Валентинов, Дмитро Громов та Олег Ладиженський. - Режим доступу: www. info-library. com /ua

5. Витоки літератури фентезі. Поезія у контексті метажанру фентезі. Збірник матеріалів наукового семінару Центру з Дослідження Літератури Фентезі при Інституті літератури ім. Т. Г. Шевченка НАН України (17 листопада 2016, 21 квітня 2017) / Ред. Рязанцева Т. М., Канчура Є. О. - Київ, 2018. - 97 c.

6. Гурдуз А. І. Міфопоетика «жіночого» містичного любовного роману першого десятиліття XXI століття в Україні / А. І. Гурдуз // Науковий вісник Миколаївського державного університету імені В. О. Сухомлинського. Сер.: Філологічні науки. - 2014. - Вип. 4. - С. 61-68.

7. Гурдуз А. Роман Дари Корній «Гонихмарник»: місце в мистецькому контексті з погляду традиції й новаторства / А. Гурдуз // Українознавчий альманах / ред. кол. : М. І. Обушний (відп. ред.) та ін. - К.; Мелітополь. -2012. - Вип. 9. - С. 229-235.

8. Дара Корній: містичні книжки у Луцьку на Хелловін [Електронний ресурс] // Волинські новини. - 1 листопада 2014. - Режим доступу: https://www.volynnews.com/news/culture/dara-korniy-mistychni-knyzhky-u-lutskuna-khellovin/

9. Ковтун Е. Н. Поэтика необычайного: Художественные миры фантастики, волшебной сказки, утопии, притчи и мифа (На материале европейской литературы первой половины XX века): монография / Е. Н. Ковтун. - Москва: Изд-во МГУ, 1999. - 308 с.

10. Козій О. Янголи XX століття: концепт крил у літературі (на матеріалі творів Г. Уеллса «Дивовижні відвідини», Г. Маркеса «Сто років самотності» та оповідання «Стариган з крилами», оповідання А. Дімарова «Крила» та вірша I. Драча «Крила») / О. Козій // Наукові записки [Кіровоградського державного педагогічного університету імені Володимира Винниченка]. Сер. : Філологічні науки. - 2009. - Вип. 85. - С. 211-219. - Режим доступу: http://nbuv.gov.ua/UJRN/Nzs_2009_85_25.

11. Корній Дара. Гонихмарник: роман/передм. Люко Дашвар ; худож. А. Срьоміна. - Харків : Книжковий Клуб «Клуб Сімейного Дозвілля», 2010. 336 с.: іл. 
12. Корній Дара, Владмирова Тала. Крила кольору хмар: роман /Дара Корній, Тала Владмирова; передм. Т. Белімової. - Харків: Книжковий Клуб «Клуб Сімейного Дозвілля», 2015. - 320 с.

13. Криницька Н. І. Архетипи у фантастичних творах Урсули Ле Гуїн / Н. І. Криницька // Вісник Харківського національного університету імені В. Н. Каразіна. - Харків : ХНУ, 2004. - Випуск 42. - № 632. - С. 368-372. (Серія «Філологія»).

14. Пташка Катя. Письменниця Дара Корній: українцям варто навчитися любити своє (інтерв'ю) [Електронний ресурс] / Катя Пташка // Український інтерес. - 12 липня 2018. - 1 Режим доступу: https://uain.press/news/accents/pysmennytsya-dara-kornij-ukrayintsyam-vartonavchytysya-lyubyty-svoye- 864875

15. Олійник С. М. Міфологеми стихій в українському фентезі / С. М. Олійник // Літературознавчі студії : зб. наук. пр. / Київ. нац. ун-т ім. Т. Шевченка, Ін-т філології. - Киӥв, 2015. - Вип. 43, ч. 2. - С. 105-116.

16. Савицкая Т. Е. Фэнтези: становление глобального жанра / T.Е. Савицкая // Культура в современном мире. - 2012. - № 2 [Электронный ресурс]. - Режим доступа: URL: http://infoculture.rsl.ru/.

17. Цалапова О. М. Міфопоетика казкового світу раннього українського модернізму (Дніпрова Чайка, Леся Українка, Олександр Олесь, Михайло Коцюбинський) : дис. ... канд. фрілол. наук: спец. 10.01.01 / О. М. Цалапова; ДЗ «Луган. нац. ун-т ім. Тараса Шевченка». - Луганськ, 2010. - 210 с.

\section{References:}

1. Bachyns'ka Kateryna. Dara Kornij: Vitchyzniane fentezi vydavtsi ne duzhe shanuiut' [Elektronnyj resurs] / Kateryna Bachyns'ka // Ukraina moloda. - 18 veresnia. - 2015 . - № 122 . $\quad$ $\quad$ Rezhym dostupu: https://vvv.umoloda.kiev.ua/number/2709/164/94873/

2. Bokshan' H. I. Neomifolohizm u khudozhnij prozi Halyny Pahutiak:-avtoref. dys. ... kand. filol. nauk: 10.01.01 «Ukrains'ka literatura»/ Halyna Ivanivna Bokshan'. - Kyivs'kyj universytet imeni Borysa Hrinchenka. - Kyiv, 2017. - 22 s.

3. Bondar Liliia. Mol'farka slova Dara Kornij: «Zapoiuschuiu ochi j bachu inshi svity» [Elektronnyj resurs] / Liliia Bondar // Volyns'ki novyny. - 2 kvitnia 2016. Rezhym dostupu: https://vvv.umoloda.kiev.ua/number/2709/164/94873/

4. Valentynov A. Zamitky pro ukrains'ku fantastyku. [Elektronnyj resurs] / Andrij Valentynov, Dmytro Hromov ta Oleh Ladyzhens'kyj. - Rezhym dostupu: vvv. info-library. tsom /ua

5. Vytoky literatury fentezi. Poeziia u konteksti metazhanru fentezi. Zbirnyk materialiv naukovoho seminaru Tsentru z Doslidzhennia Literatury Fentezi pry Instytuti literatury im. T. H. Shevchenka NAN Ukrainy (17 lystopada 2016, 21 kvitnia 2017) / Red. Riazantseva T. M., Kanchura Ye. O. - Kyiv, 2018. - 97 s.

6. Hurduz A. I. Mifopoetyka "zhinochoho» mistychnoho liubovnoho romanu pershoho desiatylittia KhKhI stolittia v Ukraini / A. I. Hurduz // Naukovyj visnyk Mykolaivs'koho derzhavnoho universytetu imeni V. O. Sukhomlyns'koho. Ser.: Filolohichni nauky. - 2014. - Vyp. 4. - S. 61-68. 
7. Hurduz A. Roman Dary Kornij «Honykhmarnyk»: mistse v mystets'komu konteksti $\mathrm{z}$ pohliadu tradytsii j novatorstva / A. Hurduz // Ukrainoznavchyj al'manakh / red. kol. : M. I. Obushnyj (vidp. red.) ta in. - K.; Melitopol'. - 2012. Vyp. 9. - S. 229-235.

8. Dara Kornij: mistychni knyzhky u Luts'ku na Khellovin [Elektronnyj resurs] // Volyns'ki novyny. - 1 lystopada 2014. - Rezhym dostupu: https://vvv.volynnevs.tsom/nevs/tsulture/dara-korniy-mistychni-knyzhky-u-lutskuna-khellovin/

9. Kovtun E. N. Poetyka neobychajnoho: Khudozhestvennye myry fantastyky, volshebnoj skazky, utopyy, prytchy y myfa (Na materyale evropejskoj lyteratury pervoj polovyny KhKh veka): monohrafyia / E. N. Kovtun. - Moskva: Yzd-vo MHU, 1999. - $308 \mathrm{~s}$.

10. Kozij O. Yanholy KhKh stolittia: kontsept kryl u literaturi (na materiali tvoriv H. Uellsa «Dyvovyzhni vidvidyny», H. Markesa "Sto rokiv samotnosti» ta opovidannia "Staryhan z krylamy», opovidannia A. Dimarova "Kryla» ta virsha I. Dracha "Kryla») / O. Kozij // Naukovi zapysky [Kirovohrads'koho derzhavnoho pedahohichnoho universytetu imeni Volodymyra Vynnychenka]. Ser. : Filolohichni nauky. - 2009. - Vyp. 85. - S. 211-219. - Rezhym dostupu: http://nbuv.gov.ua/UJRN/Nzs_2009_85_25.

11. Kornij Dara. Honykhmarnyk: roman/peredm. Liuko Dashvar; khudozh. A. Yer'omina. - Kharkiv : Knyzhkovyj Klub «Klub Simejnoho Dozvillia», 2010. - 336 s.: il.

12. Kornij Dara, Vladmyrova Tala. Kryla kol'oru khmar: roman /Dara Kornij, Tala Vladmyrova; peredm. T. Belimovoi. - Kharkiv: Knyzhkovyj Klub «Klub Simejnoho Dozvillia», 2015. - 320 s.

13. Krynyts'ka N. I. Arkhetypy u fantastychnykh tvorakh Ursuly Le Huin / N. I. Krynyts'ka // Visnyk Kharkivs'koho natsional'noho universytetu imeni V. N. Karazina. - Kharkiv : KhNU, 2004. - Vypusk 42. - № 632. - S. 368-372. - (Seriia «Filolohiia»).

14. Ptashka Katia. Pys'mennytsia Dara Kornij: ukraintsiam varto navchytysia liubyty svoie (interv'iu) [Elektronnyj resurs] / Katia Ptashka // Ukrains'kyj interes. - 12 lypnia 2018. - 12 Rezhym dostupu: https://uain.press/nevs/atstsents/pysmennytsia-dara-kornij-ukrayintsiam-vartonavchytysia-liubyty-svoie-864875

15. Olijnyk S. M. Mifolohemy stykhij v ukrains'komu fentezi / S. M. Olijnyk // Literaturoznavchi studii : zb. nauk. pr. / Kyiv. nats. un-t im. T. Shevchenka, In-t filolohii. - Kyiv, 2015. - Vyp. 43, ch. 2. - S. 105-116.

16. Savytskaia T. E. Fentezy: stanovlenye hlobal'noho zhanra / T.E. Savytskaia // Kul'tura v sovremennom myre. - 2012. - № 2 [Elektronnyj resurs]. Rezhym dostupa: URL: http://infotsulture.rsl.ru/.

17. Tsalapova O. M. Mifopoetyka kazkovoho svitu rann'oho ukrains'koho modernizmu (Dniprova Chajka, Lesia Ukrainka, Oleksandr Oles', Mykhajlo Kotsiubyns'kyj) : dys. ... kand. filol. nauk: spets. 10.01.01 / O. M. Tsalapova; DZ «Luhan. nats. un-t im. Tarasa Shevchenka». - Luhans'k, 2010. - 210 s. 


\begin{abstract}
Summary
Olena Sazonova, Anastasiia Primochenko

The Peculiarities of the Mifopoietics of Slovenian Fantasy in the Author's Interpretation of Dara Korniy and Tala Vladmirova

The peculiarities of the manifestation of the author's mythology of Dara Korniy and Tala Vladmirova in the work in "Krila koloru khmar" are considered taking into account the Slavic national tradition and foreign experience of the literary genre of fantasy. It has been revealed how the fantasy text canons and structural elements of ancient Ukrainian mythology and folklore, as woven into the artistic space of fantasy mythological representations archetype images, symbols, plots. The main problems of the work has been studied. The images of the main characters were studied and the search of their primary image was carried out in Ukrainian mythology, the functions of acting persons are distinguished.
\end{abstract}

Key words: fantasy, Slavic national tradition, mifopoietics, symbols.

Дата надходження статті: «12» лютого 2019 р.

Дата прийняття до друку: «01» березня 2019 р.

\title{
УДК 821.161.2-31.09»19»Гуменна:398:22
}

DOI: 10.31475/fil.dys.2019.09.16

ОКСАНА ТИХОВСЬКА,

кандидат фбілологічних наук, дочент

(м. Ужгород)

\section{Образ мавки в українській міфології та повісті Докії Гуменної «Небесний змій»}

У статті розглянуто специфбіку образу мавки в украӥнській міфбологї та в повісті Д. Гуменної "Небесний змій». На основі праць Ф.Потушняка, В.Шухевича, В.Гнатюка та інших дослідників з'ясовано, шо мавка сприйлалася нашили предкали $i$ як богиня рослинності, $i$ як богиня слерті. Мавка в украӥнській міфбологї постає уособленнял делонічної ббелінності (негативної Аніли), котра зводить зі світу чоловіків, наславши на них блуд (дезорієнтацію на місиевості) або зваблюе й лоскоче до слерті. Селантично близькил до образу мавки на Закарпатті є мана та повітруля, на Гуиульщині лісниия, образи всіх цих персонажів албівалентні й лають архетипну природу. Ці міббологічні персонажі увібрали в себе страх людини перед слертю та перед телною стороною власної особистості. 3 психологічної точки зору, в образі мавки-мани об'єктивувався страх чоловіків перед можливістю бути захопленили 